\title{
The Anticipation of Schools Bullying
}

\section{Eni Hidayati ${ }^{1}$, Christina Tri Cahyani' ${ }^{1}$, Desi Ariyana Rahayu', Muhammad Fatkul Mubin'1, Tri Nurhidayati ${ }^{1}$}

${ }^{1}$ Universitas Muhammadiyah Semarang, Indonesia

\section{Article Info}

\section{Article History:}

Submit Dec 2nd, 2020

Accepted Dec 28th, 2020

Published Dec 30th 2020

Keywords:

Bullying; Teacher; Junior

High School

\begin{abstract}
Bullying is an action to harm other people that continuously happen either in groups or individually. Bullying could happen in a school environment to the students who are quiet, small and to those unable to defend themselves. This study aims to determine the anticipation of bullying in the school environment. The frequency distribution test results obtained that 250 teachers were in the sufficient category in anticipating bullying prevention and 3 teachers were still in the poor category. The research hopefully can stop bullying in the school environment. Bullying is an action to harm other people which is carried out continuously either in groups or individually. Bullying could occur in a school environment to students who are quiet, small and those unable to defend themselves. Bullying prevented by regulations that could be valid to all school members. The study aims to determine the anticipation of bullying in the school environment. The frequency distribution test results obtained that 250 teachers were in the sufficient category in anticipation of bullying prevention and 3 teachers were still in the poor category. The research hopefully can stop bullying in the school environment.
\end{abstract}

\section{INTRODUCTION}

Schooling period is a time in which children begin to pay attention to their environment and playmates, at this time children spend more free time with their friends rather than staying at home or hanging out with family. We would never know whether bullying frequently happens in the school environment; there will be many victims if we do not realize the situation. ${ }^{1}$ Someone do repeated treatment who can harm others, both in the group and individually. ${ }^{2}$ Bullying usually only to hurt others and create an aggressive attitude, the perpetrator could be in groups or individuals and only targeting victims whom they think are vulnerable to attack. ${ }^{3}$

Bullying is one of the violence that appears among adolescents and can occur anywhere, especially in the school environment; bullying could be a threatening stressor. Bullying is a form of violence that hurts peers to find satisfaction in itself. ${ }^{3}$ Bullying in the school environment is verbal bullying such as taunting, calling parents 'names or changing friends' names as nicknames. ${ }^{4}$

Bullying in our country mostly occurs in the school environment; around $61-73 \%$ of

Corresponding author:

Eni Hidayati

eni.hidayati@unimus.ac.id

South East Asia Nursing Research, Vol 2 No 4, December 2020

ISSN:2685-032X

DOI: https://doi.org/10.26714/seanr.2.4.2020.25-31 
bullying cases are in the form of violence, extortion, threatening and taking things, and other forms of cyberbullying. ${ }^{5}$ Bullying behaviour is considered a common thing among school peers, so we never know that it can lead to violence. Bullying cases are already familiar in Indonesia according to the Indonesian Child Protection Commission (KPAI), there are 369 reports related to bullying that occurred in schools from 2011 to 2014, and data from the ICRW (International Center for Research On Women) in 2015 was $84 \%$ the occurrence of violence in schools, this case is the higher number compared to the trend in Asia. ${ }^{1}$

Discussion techniques on group guidance, to improve understanding of bullying behaviour, there are $75 \%$ cases of bullying in schools including verbal bullying such as mocking, insulting, cheering, calling by other names and insinuating 35\%, relational bullying such as spreading gossip, looks cynical and ostracizes 20\%, physical bullying is taking people's things without permission and coercing, stepping on their feet, pushing and hitting by $10 \%$, cyberbullying such as teasing friends through social media, giving negative comments on friend status by $10 \% .^{6}$ If these bullying cases not handled immediately, there will be more victims, it will cause other consequences such as fear, stress, anxiety, insecurity and suicide. According to the counselling teacher, students do not want to go to class because they often receive bullying from their peers. There were many cases and forms of bullying found. The perpetrator will feel satisfied when the victim feels oppressed; the perpetrators' laughter moments when playing with the victim reinforce the behaviour. ${ }^{7}$

The teacher also plays a role in developing student characteristics in school. They did not only a role model but also a motivator and inspirator. A teacher becomes a figure to be trusted and imitated by students, at the same time they can help students' development and potency; the teacher can also play a role in overcoming violence against school staff. Students play an important role in preventing bullying in the school environment. 8 Bullying can occur and cause by several factors of bullying that happen in the school environment, the lack of teachers' attention to students both in economy and achievement or student behaviour outside the classroom and inside the classrooms, teachers who are rude to students including the TV shows about violence in film scenes. ${ }^{9}$ Bullying is defined as a group of teenagers or individuals who misuse their power so that causing casualties. ${ }^{10}$ The impact of bullying for victims, they prefer to stay away from the neighbourhood or friends and become coward, while others remained silent and did not reply to the perpetrators. ${ }^{11}$

Bullying is behaviour intended to harm either directly or indirectly by a strong side to a weak side continuously. ${ }^{9}$ Bullying is also an action that carried out continuously in which involves an imbalance side such as a strong group against a weak group. ${ }^{8}$ Meanwhile, according to research ${ }^{3}$, bullying is an aggressive attack whether psychologically, verbally, socially, or physically which is carried out only for personal satisfaction. Bullying also defined as a group of adolescents and individuals who abuse the power that causes victims. ${ }^{10}$ According to study ${ }^{12}$, the forms of bullying are physical bullying, verbal bullying, nonverbal-bullying directly, nonverbalbullying indirectly, sexual abuse.

This study aims to determine the anticipation of bullying in the school environment.

\section{METHODS}

Descriptive research aims to get more accurate results from the problems under study, therefore the data collected is obtained from the results of interviews, questionnaires or observations. ${ }^{13}$ This research uses quantitative because of the data generated in the form of analysis and 
numbers using descriptive methods. Data collection using a questionnaire to find out how deep the teacher's knowledge of bullying in the school environment, then the results of the questionnaire are used as an evaluation at school.

The population is research conducted on all research objects. The population in this study consisted of 35 junior high schools in Semarang, with 35 BK teachers as respondents. The sample is a type of research that is only taken part of the research object and is considered representative of the population. ${ }^{14}$

This research uses the quantitative descriptive method. The design is quantitative descriptive. Quantitative research is systemic and usually uses an empirical, destructive, logical, and measurable approach. The quantitative research goal is to use systemic models and develop theories related to natural phenomena. ${ }^{13}$ Sampling technique using a sample of 253 respondents, the sample taken from junior high school teachers. The instrument used in this study using a questionnaire. The questionnaire consists of questions that contain anticipation of the occurrence of bullying at school.

\section{RESULTS}

Based on table 1 above, the results obtained from 253 respondents, the anticipation of teachers of school bullying include in the category quite are 250 respondents (98.8\%), while the anticipation of teachers against the occurrence of bullying in schools includes in category less are three respondents (1.2\%). Based on table 1 above, the results show that of the 253 respondents who got information sources from television as many as 224 respondents
(88.5\%), there were 169 respondents (66.8\%) who got information sources from the print media peers were 126 respondents (49.8\%), 34 respondents $(13.4 \%)$ received information sources (13.4\%), 17 respondents $(8.0 \%)$ received information sources information from others there are 20 respondents (8.0\%).

Based on table 2 above, the results show that of the 253 respondents, the respondents' answers were based on the research objectives of punishment at school which was included in the correct category in item 18 in how to prevent bullying at school there were 241 respondents (96.4\%) while those who were included in in the wrong category there were 12 respondents $(3.6 \%)$, in the twentieth item the antibullying program in schools that was included in the correct category was 156 respondents (62.4\%) while those who were in the wrong category were 97 (37.6\%), the second item, one way we respond to bullying actors, there are 245 respondents (98\%) who answered incorrectly and 8 respondents (2\%) answered incorrectly, the third item, one way so that bullying does not occur at school, there are 245 respondents (98\%) who answered correctly and 8 respondents (2\%) who answered incorrectly.

Table 1

Distribution of the frequency of teachers'

\begin{tabular}{lcc}
\multicolumn{3}{c}{ anticipation and information sources $(\mathrm{n}=253)$} \\
\hline Indicators & $\mathrm{f}$ & $\%$ \\
\hline Anticipate teachers & & \\
$\quad$ Enough & 250 & 98.8 \\
Less & 3 & 1,2 \\
\hline Resources & & \\
Television & 224 & 88,5 \\
Print media & 169 & 66,8 \\
Peers & 126 & 49,8 \\
Health workers & 34 & 13,4 \\
Social media & 17 & 8,0 \\
Other & 20 & 8,0 \\
\hline
\end{tabular}


Table 2

Distribution of the frequency of respondents' answers based on research purposes on punishment

\begin{tabular}{|c|c|c|c|c|}
\hline \multirow{3}{*}{ Question item } & \multicolumn{4}{|c|}{ Answer the Questions } \\
\hline & \multicolumn{2}{|c|}{ Correct } & \multicolumn{2}{|c|}{ Wrong } \\
\hline & $\mathrm{f}$ & $\%$ & $\mathrm{f}$ & $\%$ \\
\hline How to prevent school bullying & 241 & 96,4 & 12 & 3,6 \\
\hline Stop bullying program at school & 156 & 62,4 & 97 & 37,5 \\
\hline What are the ways we deal with bullying & 245 & 98 & 8 & 2 \\
\hline What are the ways to prevent bullying from happening at school & 145 & 98 & 8 & 2 \\
\hline
\end{tabular}

\section{DISCUSSION}

Bullying considered as a common thing and bullying also used as an encouragement for its victims to make themselves better person, some bullying victims' show that they do not deserve to bullied and they choose to fight the perpetrator by bullied them back. ${ }^{15}$ The impact of bullying for the perpetrator is that they will regret the action he has done when the victim prefers to remain silent and does not reply to the perpetrator. Meanwhile, to prevent bullying, families can teach good behaviour to their children at the early childhood stage, so that they can behave well when they are outside the home. ${ }^{10}$

Based on the research that done, there were 4 items of the punishment given by the teacher when a student makes a mistake, and those that include in the most significant number and most correct answers are in items 21 and 31 with the total of 245 respondents, and the most numbers of the wrong answer were in item 20 with a total of 97 respondents. Finding out the role of teachers and counsellors in guiding or solving problems, from the research conducted on 253 teachers were consisting of 3 items included in the correct answer category, most of which were in item 33 as many as 248 respondents and teachers whose answer was wrong mostly found in item 34 with the total of 45 respondents.

Bullying is an incident that often found in adolescents, which can have an impact on victims in mental, physical and other psychosocial health disorders. ${ }^{16}$ Bullying is also defined as vicious behaviour done intentionally and continuously to injure someone physically and mentally. It carried out by one person or group resulted in an imbalance of power or strength. ${ }^{17}$ Bullying itself is also defined as behaviour carried out repeatedly by behaving in aggression and targeting weak children according to the perpetrator, by threatening or disturbing the victim so that the affected victim suffer psychological disorders. ${ }^{18}$

On the question item about finding out the discipline rules given by the school, from the research that have done on 253 teachers, there are 5 question items and the correct answers are in item 23 as many as 244 respondents, and the most incorrect answers are in item 22 as many as 153 teachers. Finding out the regulations from the Minister of Education and Culture that applied in schools, from the research have done on 253 teachers, there are 2 items and the teachers who are correctly answering the questions in item 37 as many as 212 respondents, and those who answer incorrectly in item 40 were 68 respondents.

From the research that I have done, there are 253 teachers, there are 2 items and teachers who are in the category of the most number of correct answers are in item 37 as many as 212 teacher respondents, and the most incorrect answers in item 40 are 68 respondents who answered incorrectly. At school, some teachers become places to learn and achieve development according to targets, as for counselling teachers or counsellors who have a role to help students prevent or deal with problems that are happening to them and overcome the 
violence and sexual harassment they are experiencing. ${ }^{9}$

Find out the role of teachers and counsellors in guiding or solving problems. From the research I did, 253 teachers were consisting of 3 items that were included in the correct answer category, most of which were in item 33 as many as 248 respondents and teachers whose wrong answers were mostly found in item 34 with a total of 45 respondents. Regulations in the discipline given by schools such as implementing socialization for children about bullying and its consequences of bullying in student life at a later date. ${ }^{19}$ Teachers always assist students in the school environment both in the learning process and in behaviour outside of learning in school. Provide various kinds of learning models so that children can interact and work together and respect each other with other friends. Provide strict rules to prevent bullying and give sanctions to students who commit bullying. ${ }^{20}$

Bullying in adolescents still exists in the school environment without any warning and sanctions given to the perpetrators, which causes much more bullying victims to come out. Teachers' role is very important to prevent bullying in the school environment; the explanations of bullying are needed to create a comfortable and safe environment and avoid bullying. There are many reasons for students to do bullying in school, first is that they do not care for each other between friends that makes the higher number of bullying; second, the perpetrators are also victims of bullying; the third is that the perpetrators do bullying so that they would be considered great and feared by many people, fourth is the need to do revenge. ${ }^{21}$ Another reason students do bullying because they do not know the impact of bullying behaviour; for students who know and understand the impact of bullying, they will not do it. ${ }^{22}$

If the bullying case is not handled immediately, there will be more victims and it will cause impacts such as fear, stress, anxiety, insecurity and suicide. According to the counselling teacher, students do not want to go to class because they often receive bullying from their peers. So many cases and forms of bullying. ${ }^{23}$ The perpetrator will feel satisfied when the victim feels oppressed, the laughter of a group of perpetrators when playing with the victim reinforces the behavior. ${ }^{7}$ The teacher plays a role in shaping the characteristics of students in school, apart from being a role model, the teacher also acts as a motivator and inspirator, a teacher becomes an example of a figure to be digested and imitated by students when being an inspiration the teacher can help students develop and have potential, the teacher can also play a role in overcoming violence against school staff students also plays an important role in preventing bullying in the school environment. ${ }^{8}$

\section{CONCLUSION}

Teachers in junior high schools apply sanctions (guidance) for victims or perpetrators of bullying. Each school teacher also provides lessons about bullying and teaches good relationships between teachers, students, and other friends. The school applies discipline regulations such as Educating the students about bullying and its consequences in the future. Teachers always assist students in school, both in the learning process and students' behaviour outside of the school area's learning process. School provides various learning models for students to interact and work together and respect each other between friends. School provides strict rules to prevent bullying and give sanctions to students who commit bullying. Several schools have implemented regulations given by the Minister of Education and Culture (Mendikbud) to prevent bullying in schools. 


\section{ACKNOWLEDGMENTS}

We would like to thank the teachers and friends who provided additional information for the school to prevent bullying. The school can do it well and correctly so that there will be no victims and violence in the school environment and a comfortable and safe environment is created.

\section{CONFLICTS OF INTEREST}

Every school is obliged to implement strict rules for preventing bullying if teachers do not pay attention to students or apply strict bullying regulations, it is feared that many students will become victims of bullying without the knowledge of teachers and other school members.

\section{REFERENCES}

1. $\quad$ Aini D. Voor En Na de Oorlog. Vol 6. s.n.]; 2018.

2. Darwin, Mubin MF, Hidayati E. Pengalaman Siswa Yang Mendapatkan Bullying Di SMAN 15 Semarang. $J$ Keperawatan Komunitas. 2018;2(1):1-6.

3. Yuliani N. Fenomena kasus bullying di sekolah. Published online 2019.

4. Sutanti R. Hubungan pola asuh orang tua dengan kejadian bullying pada remaja di SMPN 06 Yogyakarta tahun 2018. Published online March 2019.

5. Nurbaiti AE, Affarah L, Sulistya W, Kadriyan H. Skrining dan Edukasi Pencegahan Bullying Pada Siswa SMA Negeri Di Kota Mataram. J Pengabdi Magister Pendidik IPA. 2019;1(2). doi:10.29303/jpmpi.v1i2.245

6. van der Ploeg R, Steglich C, Veenstra R. The way bullying works: How new ties facilitate the mutual reinforcement of status and bullying in elementary schools. Soc Networks. 2020;60(January):71-82.

doi:10.1016/j.socnet.2018.12.006

7. Goleman D, Boyatzis R, Mckee A. Bimbingan Kelompok dengan Teknik Sosiodrama Sebagai Upaya Mengatasi Perilaku Bullying di Sekolah.J Chem Inf Model. 2019;53(9):1689-1699. doi:10.1017/CB09781107415324.004

8. Putri fellinda arini. Strategi_Guru_Dalam_Meningkatkan_Minat_B. Published online 2016:62-76.
9. Kartianti S. Peran konselor dalam mengurangi perilaku bullying siswa di sekolah. Hibualamo Seri Ilmu-Ilmu Sos dan Kependidikan. 2017;1(1):34-37.

10. Citrawathi DM. Pengembangan Model Pendidikan Kesehatan Integratif Dan Kolaboratif Di Sekolah. Vol 0.; 2014.

11. Kharis A, Ain N. Dampak Bullying Terhadap Perilaku Remaja ( Studi pada SMKN 5 Mataram ). 2019;7(1):44-55.

12. Wibow AP. Penerapan Hukum Pidana Dalam Penanganan Bullying Di Sekolah - Antonius P.S. Wibowo - Google Buku.; 2019.

13. Putra SR. Panduan Riset Keperawatan Dan Penulisan Ilmiah. (Rusdianto, ed.). D-Medika; 2012.

14. Prof. Dr. Soekidjo Notoatmodjo. Ilmu Perilaku Kesehatan. Rineka Cipta. Published online 2018:75.

15. Rambaran JA, van Duijn MAJ, Dijkstra JK, Veenstra R. Stability and change in student classroom composition and its impact on peer victimization. $J$ Educ Psychol. 2020;112(8):1677-1691. doi:10.1037/edu0000438

16. Moffat AK, Redmond G, Raghavendra P. The Impact of Social Network Characteristics and Gender on Covert Bullying in Australian Students with Disability in the Middle Years. J Sch Violence. 2019;18(4):613-629. doi:10.1080/15388220.2019.1644180

17. Strindberg J, Horton P, Thornberg R. Coolness and social vulnerability: Swedish pupils' reflections on participant roles in school bullying. Res Pap Educ. 2020;35(5):603-622. doi:10.1080/02671522.2019.1615114

18. Stephen K, Aine M. UCC Library and UCC researchers have made this item openly available. Please let us know how this has helped you. Thanks! Published online 2019. doi:10.1080/15401383.2019.1623147

19. Bork-Hüffer T, Mahlknecht B, Kaufmann K. (Cyber)Bullying in schools-when bullying stretches across cON/FFlating spaces. Child Geogr. 2020;0(0):1-13. doi:10.1080/14733285.2020.1784850

20. Dardiri A, Hanum F, Raharja S. The bullying behavior in vocational schools and its correlation with school stakeholders. Int J Instr. 2020;13(2):691-706. doi:10.29333/iji.2020.13247a

21. Hellström L, Beckman L. Adolescents' perception of gender differences in bullying. Scand J Psychol. 2020;61(1):90-96. doi:10.1111/sjop.12523 
22. Thornberg R, Delby H. How do secondary school students explain bullying? Educ Res. 2019;61(2):142-160. doi:10.1080/00131881.2019.1600376

23. Kurniasih N, Wanabuliandari S, Ristiyani R. Bibliometrics Analysis in Articles of Verbal
Bullying in Schools DigitalCommons @ University of Nebraska - Lincoln Library Philosophy and Practice (e-journal ) Bibliometrics Analysis in Articles of Verbal Bullying in Schools Nuning Kurniasih. Libr Philos Pract. 2020;4087(January):1-10. 